\title{
Problems facing Islamic education: evidence from Nigeria
}

\author{
S. A. Kazeem ${ }^{1}$, K. Y. Balogun ${ }^{2}$ \\ ${ }^{1}$ Department of Islamic Studies, Michael Otedola College of Primary Education, \\ Noforija, Epe, Lagos State, Nigeria \\ ${ }^{2}$ Department of Arabic Studies, Michael Otedola College of Primary Education, \\ Noforija, Epe, Lagos State, Nigeria
}

\begin{abstract}
This study examines problems facing Islamic education in Nigeria. Primary and Secondary methods of data collection are used. Survey research design is adopted in this study. Self-structure questionnaire is raised and used to acquire information from the respondents relevant for testing hypothesis of the study. Chi - square $\left(\mathrm{x}^{2}\right)$ technique was adopted for data analysis and hypothesis testing which revealed the findings of the study that Islamic education has been confronting with the challenges of acceptability, resources and enlightenment among nominal Muslims and Christians. Islamic education has not promotes Islamization of knowledge aims at reshaping all the branches of human knowledge; humanities, pure and applied sciences in accordance with the Islamic view and reality. The study recommended that there should be vigorous enlightenment campaign showing the merits of this exercise and fruits of its success. Systematic campaign and enlightenment programme should be given priority attention otherwise the idea would be misconstrued and negatively presented to members of the public.
\end{abstract}

Keywords: Islam; Islamic Education; Islamization of knowledge; Nominal Muslim; Allah

\section{INTRODUCTION}

Islamic education is one of the best systems of education which makes an ethical groomed person with all the qualities, which he/she should have as a human being. Also Islamic education is primary viewed as divinely revealed and thus prepares individuals to be upright citizens on earth and to ultimately attain happiness in the life after death. It is revealed from the definitions above that God is the centre and focus of Islamic education; hence to be educated, a muslim must be devoted to attaining the pleasure of God. This should result in pious actions that would enable the muslim to draw closer to God. The only way this can be achieved is according to the divine revelation, being the Book Quran and the example left by the Prophet Muhammad (Peace be upon him) (Yoloye, 2008).

Education in Islam is regarded as a process that completely nurtures the individual. Education should aim at the balanced growth of the total personality of man through the training of man's spirit, intellect, rational self, feelings and bodily senses, such that faith is infused into the whole of his personality. In Islamic theology, knowledge is gained in order to actualize and perfect all the dimensions of the human. The paradigm of perfection is the Prophet (Peace be upon him), and thus the goal of Islamic education is for muslims to live as he (Peace be upon him) lived and to imitate him (Khalil, 2007). 
In view of Olaoti (2010), education is an important factor in the development of any society. The level of development of any nation is usually determined by its level of education. At same time the nature of education available to any community, will depict how the affected community would look like. It is this context that makes it paramount for Muslims to look inwardly into the situation we find ourselves today politically, socially, economically, and spiritually. Without mixing words, everybody will testify that the nature of education bequeathed to us by our former colonial masters is alien to our culture and has failed woefully to meet our aspirations when one considers the evils that have plagued our society. Thus, this present study examines the problems facing Islamic education in Nigeria. The study was divided into five sections. Following this section, was section two which focus on conceptual framework, section three discussed methodology and design of the study, section four dealt with the data analysis and interpretation of the results. Finally, section five embraced conclusion and recommendations for the study.

\section{CONCEPTUAL FRAMEWORK}

\section{1. Islamic Educational System in Nigeria}

The history of Islamic education in Nigeria is the same as the history of the religion of Islam itself. This is because Islam goes to any place or community along with its own form of education (Balogun 1982 and Ajidagba, 2012). Islam, which predates Christianity in Nigeria, is said to have come to the country in the 11th century. It is on record that when Kanem Ummi Jilmi of the old Borno accepted Islam, he established the first Quranic School in his palace. It is not a matter of coincidence or accident that Islamic religion and Islamic education go together. The fact is that, without the latter the former cannot be said to have been firmly entrenched and understood. The Holy prophet was reported to have said that, "if Allah wants to do good to a person, he makes him to understand the religion (Bukhari, 3:11).

Therefore, there is no pretence or cover up, about the objective of Islamic education. It thrives on the Islamic concept of life, here and hereafter, prescribing the individual's position and role on earth (Qutub, 1977). The structure of the early Islamic education was Allah on the hierarchical structure of the Islamic faith. The first and the only reference and rallying point is Allah, the Creator and the starting point is to learn how to recite Al-Qur'an, the words of built. The early Islamic recitation, a student would then begin to study further under an erudite Mallam (teacher) who may not necessarily be the only teacher to handle the student till he himself becomes highly knowledgeable in the field.

In Nigeria, the Ansarul-lslam Society of Nigeria, a foremost Islamic society and the first Islamic organization in the North, which was established in 1942, is credited for being the vanguard of the formal Islamic system of education in Nigeria. Until the society introduced the formal school system, whereby students sit on benches in a typical classroom manner, Islamic education was handled non-formally in the residence of the Mallam. It should be pointed out here that there had not been either any form of government assistance or foreign aid to Islamic education as at that time. In spite of this segregate attitude of the government, Islamic education continued to grow along with the increasing population of Muslims in the country. The scenario today is that of a complete transformation of the system, a wholesome improvement on the pioneering effort of the Ansarul-lslam society of Nigeria. Islamic educational system now competes with its western counterpart in structure and infrastructure.

We now have the Ibtidai up to Jamiah levels (Primary to University). Similarly, there are many Islamic educational institutions that have all the paraphernalia of the modern school systems. Such schools operate programmes and activities on terminal basis, go on short and long vacation and have incorporated co-curricular activities into their programmes. Yet, the 
government of Nigeria especially at the federal level has not deemed it fit to accord Islamic education it is rightful recognition.

\section{2. Factors Inhibiting the Development of Islamic Education in Nigeria}

The factors militating against the development of Islamic education are multifarious but, they are all artificial and not, therefore, insurmountable. They could be grouped as relating to government, the proprietors, parents, the society and the media.

\section{3. Government}

A study of this nature cannot adequately do justice to the inhibitive roles successive governments have played on Islamic education in Nigeria. On funding, the government not only fund Western education, it has also taken over its full control. So, what started as mere grant-in aid soon graduated into full take-over. This alone has a negative consequence on the said, at this juncture, that no right- thinking person would literally condemn the content of western education because, after all, if the English version of all that had already been known to the Muslims years back. The point, however is that its incursion into this country with strong connection with Christianity has led to dislocation of the older Islamic order in traditional Muslim society. It has been repeatedly said that Muslims constitute a large percentage of Nigerians. In order to be fair and just to this large Muslim population, Islamic education should be accorded a more dignified attention than it is presently being given. Even, if only for spiritual and moral development, which the National Policy on Education (1981) advocates for, government should be more interested in Islamic education.

\section{4. Muslim Proprietors}

The problems being created by the proprietors of Islamiyyah schools for Islamic educational system can be likened to a proverbial kola nut having a problem of the parastic insect living in it. The problem is multi-dimensional. Dishonest proprietors go to some Arab countries' governments or philanthropists, cap-in-hand, to seek financial assistance only to come back home to divert such assistance to personal use. Some also go to the ridiculous level of selling the valuable Islamic textbooks given them for the propagation of Islam and the development of Islamic education. The worst category is the absentee-proprietors who do not have $1 / 10$ of the students and facilities they claim to have and would do one launching after the other in the name of development of their institutions. More worrisome is lack of unity among the proprietors even within the same locality. This made it impossible for them to have a forum to articulate their views on how to move the system forward.

\section{5. Muslim Parents}

Muslim parents of students in Islamiyyah schools have their own share of the problem. The disdainful manner in which students attending Islamic schools does more harm than good. An average Nigerian Muslim parent does spend heavily on Western education for their children. Some take Islamic education as secondary; while some send to Islamic schools, the children who, in their opinion and conclusion, cannot mentally cope with Western education or who have one form of disability or the other.

\section{6. The Society}

What is happening in the society is a reflection of what happens in the family. The Nigerian society does not see any thing beneficial in the Islamic system of education other than the religious knowledge. There is an impression that anybody undertaking Islamic 
education can only function either as a full time Mallam (a teacher) with teaching being a profession that is already looked down upon. Not only this, in some religiously hostile communities, Islamic education is derisively regarded as education for the Al-majiris (corrupt form of AI-Muhajirin), which originally means the immigrants but misconstrued to be beggars. No thanks to some Muslims who have upgraded begging to an art and a profession. Unfortunately too, Numerous uninformed Muslims have been persuaded by this anti-Islamic posture. In Yoruba land there is what people derogatorily called ole Intel'Afa - meaning, it is an indolent that follows a Maljiris. And as if to lend credence to the saying, it is a common thing to see pupils that are put under the care of some Mallams for Islamic upbringing, going about begging. It is high time we turned things around for Islamic education. It is our collective responsibility to enlighten the populace that Islamic education is a utilitarian education (Ajidagba, 2012).

\section{7. Mass Media}

The most decmactive and vociferous attack on Islamic education or anything Islamic is always championed by the mass media in Nigeria, a keen watcher of events may not be too astonished about this situation because, the Nigerian press can aptly be described as a Christian press, for the simple reason that Christians own or control over $90 \%$ of the media outfits (print or electronics) in the country. The comparative edge the Western educational system has over its Islamic counterpart can be credited to the ceaseless propaganda of the press. Even when Muslims have been the President or Heads of State, there has been overt and covert government backing of the press. Whereas, the mass media is a strong agent of education and mobilization, as far as Islamic education is concerned, it is a combative agent of mis-education and demobilization. To arrest the trend, the gifted Muslims should brace up to the challenged by not clear vocational articles, while the rich Muslims should be encouraged to establish media outfits that could assist in this direction. Submission to Allah is based on humility. An attitude of humility within one's self cannot be accomplished without total rejection of violence, and a personal attitude and alignment toward peace and development.

\section{8. Aims and Objectives of Islamic Education}

Every educational system has its own objective likewise Islamic education, except that Islamic education is deeper and richer both in content and objective. In realizing this fact the participants at the First World Conference on Muslim Education in 1977 at the end of the Conference reaffirmed this and resolved that: Education should aim at the balanced growth of the total personality of man through the training of man's spirit, intellect, rational self, feelings and bodily senses, The training imparted to a Muslim must be such that faith is infused into the whole of his personality and creates in him an emotional attachment to Islam and enables him to follow the Qur'an and the Sunnah and be governed by Islamic system of values willingly and joyfully so that he may proceed to the realization of his statue as Khalifatullah to whom Allah has promised the authority of the universe.

This in summary shows that the aim of Islamic education is to produce a good and righteous man, he who worships Allah the Creator and acts according to the dictates of Shari'ah. This act of worship requires total submission to Allah as it is supposed to be in line with Quranic verse that says: "I have created the Jinn and man only to worship me" (Qur'an $51: 56)$.

This position does not mean that Islamic education is against other secular sciences, Islamic education as earlier mentioned is wide and comprehensive. It encompasses all sciences, either secular or religious. The Qur'an says. "Nothing have we omitted from the 
Book," (Qur'an 6:38). From this we can deduce that Islamic education comprises of other sciences such as medicine, engineering, mathematics, psychology, sociology etc., because they are also Islamic sciences once they comply with Islamic tents and attitudes.

Ahmed (1979) opined that Islamic Science is a form of worship that moves an individual closer to his creator through the act of worship, hence it should not be used to corrupt faith and morals and to bring harm, corruption, injustice and aggression. So any science that runs conflict with and serves other goals contrary to Islamic ideals is condemned and rejected and lastly has no place in the Islamic injunctions. Since education has been universally accepted as an important tool for the guiding of lives of people created by Allah, its philosophy and basic principles should also come from Allah. It should not be left alone to the discretion of educationist who is themselves subject to all manners of unwholesome influences.

Oloyede (2008) asserts that the tragedy of education in Nigeria is that it has failed in the development of social consciousness within students, its most important basic task, rather it has created the opposite of happiness (destroying) preoccupying them with immediate personal and material satisfaction. It has failed in preparing students for adult life. If the above opinion is correct, then it is pertinent to have an alternative that commensurate with Islamic values of education, and that is Islamization of education. The fact that Muslims all over the world have realized that the alien system has failed as both in content and objectives, then we should return to that which emanates from the divine source. The alien system separates between religion and life and does not recognize the supremacy of religion. The modern education also considers this life as an end in itself contrary to Islamic education which provides for hereafter and for this gives recognition to the supremacy of religion. It is worthy enough to say here that Islamic education that disregards religious moral teaching is doomed to fail.

Afzalur (2000) posits that if education is divorced from religion and moral values, it will lead to the disintegration and destruction of the social fabric of society. This may be seen from the achievements of liberal education in the West as well as in the East. Education has divorced itself from the spiritual heritage of the past but has failed to supply any adequate substitute. Consequently, even educated persons are left without convictions of a sense of values as well as without a consistent world view.

It is unfortunate that our leaders are pretenders they go out crying that Nigeria is a secular state when documents see Nigeria as a multi-religious country. To show that it is not easy to separate people from their religion under whatever disguise, the Political Bureau further says that religion has deeply affected our cultural, political and social heritage that it is very difficult though necessary to distinguish what is traditional from what is religious. At the end of the debate, the Political Bureau conceded that it is difficult to achieve a clear separation between organized religion and the state in Nigeria (Afzalur, 2000).

This position of the political bureau depicts the ulterior motives of our secularist leaders but at the end they could not hide the fact that religion is not an institution that can easily be taken away from the people and so proclamation of secularism on Nigeria will continue to be a theory. The secularist nature of our educational curriculum has succeeded in producing various corrupt practices such as inflation of contracts, fraud, falsification of accounts, examination malpractice, bribery, embezzlement of public funds, perversion of justice, collusion with multi-national companies to dupe the state, collusion of law enforcement agents with criminals, election rigging, etc. If these are the manifestations of the philosophy of secular education, we cannot tolerate a philosophy or any educational policy which is not identical with Islam (Afzalur, 2000). 
In total, the ultimate objective of Islamic education is the creation of an individual who will lead a happy and fruitful life in this world and use it to aspire for a better life in the hereafter.

\section{9. Problems Facing Islamic Education in Nigeria}

The above discussion on the aim and objectives of Islamic education compared with the western or modern concept of education shows clearly that they are not equal. It is like comparing the giant with the dwarf or the day and the night in all ramifications. Islamization of education is as old as Islam itself. It is a continuation of effort made by the early scholars like Imam al-Ghazali, Ibn Taimiyyah, Muhammad Iqbal and others to reconcile the knowledge of their time with the spirit of Islam. The single aim is to recast knowledge to conform to the Islamic belief system and worldview. The term Islamization of knowledge means practicing (i.e. discovering, compiling, piling together, communicating and publishing) intellectual activities based on the Islamic concept of the universe, life and man (Khalil, 2007). So for Islamization of knowledge to succeed it has to contend with the following problems:

i. Acceptability: For the problem of acceptability, some people will consider the programme as a way of Islamizing the citizens of Nigeria just as the colonialists and the missionaries used the western education to convert the indigenes to Christianity. In this wise, the Christians and some nominal Muslim would frown at it and are likely to frustrate any attempt to make it possible, in the same vein as they opposed the full implementation of shari'ah.

ii. Resources: The area of resources is also very vital. For a pragramme of this nature to succeed it requires both human and material resources. The programme would definitely face the problem of manpower. There are no enough personnel to man the programme. If we can source for personnel in other in some areas locally we may need the service of expatriates in other areas. The major areas that may require expatriates are science and Technology. The nation has not produced enough personnel in these areas least of those that would be used for the Islamization programme. Still along the resources is provision of reading materials we cannot hope for achieving anything tangible except books are written by learned and committed Muslim intellectuals.

iii. Enlightenment: Another problem is enlightenment. Men are enemies of what they are ignorant about. The concept of Islamization of education is alien to some people even if it would benefit them at the end, they show antagonism to it at initial stage. Some would interpret it to mean introduction of shari'ah. One should not be surprised if one discovers that the first antagonists are Muslims, the unenlightened ones. Their reaction to the idea would add impetus to that of the non-Muslims. In the light of this, conscious Muslims in the mass media should enlighten Nigerians on the viability of the programme and emphasize its short and long term benefits for all.

iv Government Patronage: The chance of patronage from government is low. Government will not allow any individual or group of individuals to use her school for such a programme under the guise of secularity and national character. 


\section{RESEARCH METHODOLOGY AND DESIGN}

\section{1. Research Design}

Research design is a blue print of activities or specification of procedure and strategies to follow so as to obtain the most valid answer to research question or attain the objectives of the study with optimal control of variance and the make up of carefully articulated set of suggested instruction for the effective of the study (Hassan, 2008). This study was carried out to bring to the fore "The Problems facing Islamic Education in Nigeria" therefore, survey research design is used.

\section{2. Sources and Methods of Data Collection}

This study specifically used primary and secondary methods of data collection. The primary data included the data collected from the questionnaire administration while secondary data included the used of relevant journals and text books for the study write-up.

\section{3. Hypothesis}

$\mathbf{H}_{\mathbf{0}}$ : Islamic education in Nigeria has not been confronting with the challenges of acceptability, resources, and enlightenment among nominal Muslims and Christians.

$\mathbf{H}_{\mathbf{1}}$ : Islamic education in Nigeria has been confronting with the challenges of acceptability, resources, and enlightenment among nominal Muslims and Christians.

\section{4. Population, Sample and Sampling Techniques}

The population of this study comprised of all students of Micheal Otedola College of Primary Education, Noforija, Epe, Lagos State Nigeria. Sample is the subset of the population, for the purpose of this study, only two hundred and fifty (250) students were involved in the questionnaire administration for the study.

\section{5. Estimation Techniques}

Frequency percentage count is used for presenting the data collected from the questionnaire administration. For the purpose of hypothesis testing, Chi - square $\left(\mathrm{x}^{2}\right)$ analysis was used to justified the study outcomes.

\section{DATA ANALYSIS}

The below table represents the general opinion of the respondents on the issue raised in this study: 
Table 1. Contingency Table (Observed Frequency).

\begin{tabular}{|c|c|c|c|c|c|c|}
\hline Statements & SA & $\mathbf{A}$ & $\mathbf{U}$ & SD & D & Total \\
\hline $\begin{array}{l}\text { Islamic education in Nigeria has been } \\
\text { confronting with the challenges of } \\
\text { acceptability, resources and enlightenment } \\
\text { among nominal Muslims and Christians. }\end{array}$ & 131 & 83 & 7 & 13 & 16 & 250 \\
\hline $\begin{array}{l}\text { Islamic education has not produce a good } \\
\text { and righteous man, he who worships Allah } \\
\text { the creator and acts according to the dictates } \\
\text { of Shari'ah. }\end{array}$ & 101 & 59 & 15 & 38 & 37 & 250 \\
\hline $\begin{array}{l}\text { Islamic education has not acts as a form of } \\
\text { worship that moves an individual closer to } \\
\text { his creator through the act of worship. }\end{array}$ & 127 & 80 & 11 & 15 & 17 & 250 \\
\hline $\begin{array}{l}\text { Islamic education has not creates an } \\
\text { individual who will lead to a happy and } \\
\text { fruitful life in this world and use it to aspire } \\
\text { for a better life in the hereafter. }\end{array}$ & 93 & 66 & 17 & 43 & 31 & 250 \\
\hline $\begin{array}{l}\text { Islamic education in Nigeria has not } \\
\text { promotes Islamization of knowledge aims at } \\
\text { reshaping all the branches of human } \\
\text { knowledge, humanities, pure and applied } \\
\text { sciences in accordance with the Islamic view } \\
\text { and reality. }\end{array}$ & 117 & 60 & 9 & 29 & 35 & 250 \\
\hline & 569 & 348 & 59 & 138 & 136 & 1250 \\
\hline
\end{tabular}

Source: Author Computation

Therefore, Expected frequency (E) is calculated as follow:

$\mathrm{E}=\frac{\mathrm{RT} \times \mathrm{CT}}{\mathrm{N}}$

where RT $=$ Row total $\mathrm{CT}=$ Column total and $\mathrm{N}=$ Grand total

For $\mathrm{SA}, \quad \mathrm{E}=\underline{250 \times 569}=113.8$

$$
1250
$$

For $\mathrm{A}, \quad \mathrm{E}=\underline{250 \times 348}=69.6$

For $\mathrm{U}, \quad \mathrm{E}=\frac{250 \times 59}{1250}=11.8$

For $\mathrm{SD}, \quad \mathrm{E}=\underline{250 \times 138}=27.6$

For $\mathrm{D}, \quad \mathrm{E}=\underline{250 \times 136}=27.2$ 1250 
Table 2. Chi-square $\left(\mathrm{x}^{2}\right)$ Analysis Technique.

\begin{tabular}{|c|c|c|c|c|c|}
\hline Responses & $\mathrm{O}$ & $\mathrm{E}$ & $\mathrm{O}-\mathrm{E}$ & $(\mathrm{O}-\mathrm{E})^{2}$ & $(\mathrm{O}-\mathrm{E})^{2} / \mathrm{E}$ \\
\hline SA & 569 & 113.8 & 455.2 & 207207.04 & 364.16 \\
A & 348 & 69.6 & 278.4 & 77506.56 & 113.6 \\
$\mathrm{U}$ & 59 & 11.8 & 47.2 & 227.84 & 188.8 \\
SD & 138 & 27.6 & 110.4 & 12188.16 & 441.6 \\
D & 136 & 27.2 & 108.8 & 11837.44 & 435.2 \\
\hline & & & & & 2543.36 \\
\hline
\end{tabular}

Source: Author Computation

The above result show that in observed case, chi-square calculated $\left(\mathrm{x}_{\mathrm{c}}{ }^{2}\right)$ is 2543.36 while chi-square $\left(x_{t}^{2}\right)$ is 7.815 at $5 \%$ level of significance. Thus, it revealed that $x_{c}{ }^{2}>x_{t}^{2}$, meaning that the observed frequencies differ significantly from the expected frequencies. Hence, $\mathrm{H}_{0}$ (Null hypothesis) is rejected while $\mathrm{H}_{1}$ (Alternative hypothesis) is accepted. The implication of this result is that Islamic education in Nigeria has been confronting with many challenges such as acceptability, resources and enlightenment e.t.c., among nominal Muslims and Christians.

\section{CONCLUSION AND RECOMMENDATIONS}

\section{Conclusion}

Islamic education embraces the teaching of Islam doctrines through effective education to ensure that the outputs from this system can be worth wide and benefited to the society and also embraces the five pillars of Islam. Therefore, this study concluded that Islamic education in Nigeria has been confronting with the challenges of acceptability, resources and enlightenment among nominal Muslims and Christians. Islamic education has not produce a good and righteous man, he who worships Allah the creator and acts according to the dictates of Shari'ah. Islamic education has not act as a form of worship. Islamic education has not creates an individual who will lead a happy and fruitful life in this world and use it to aspire for a better life in the hereafter. Finally, that Islamic education in Nigeria has not promotes Islamization of knowledge aims at reshaping all the branches of human knowledge, humanities, pure and applied sciences in accordance with the Islamic view and reality.

\section{Recommendations}

The following are the recommendations provided for the study:

* Human and Material Resources: Efforts should be made in training manpower for the programme. Schools should be established specifically for this purpose because without manpower the programme is doomed to fail. Institutions like International Islamic University in Malaysia, Niger, Uganda and Pakistan Usmanu Danfodio.

Also in the same wing is provision of reading materials and other infrastructures. The current books in circulation are irrelevant to our desire. So many Muslim scholars should be encouraged to write books relevant to our demands. 
* Scholarship Award: Scholarship award should be made available for prospective candidates without any discrimination. There should be no quota system or National character. If this is introduced, it will adversely affect the system.

* Commitment to Teaching Profession: Muslims should be encouraged to show commitment to teaching profession; a situation where Muslims who are professionally qualified to teach prefer administrative jobs cannot help. It will be a daydream to expect non-Muslims to promote this laudable programme.

* Standardization of Our Mainstream Islamic Education: Our traditional Qur'anic schools should be standardized and reinvigorated so as to meet the current demand. This could be done by establishing Muslim nursery and primary schools based on Islamic curriculum. This should not be limited to primary alone, but including secondary levels.

* Support from Well-Wishers: The well-to-do (rich) Muslims, the businessmen and other Islamic organizations both at home and abroad should spare no effort in assisting the programme. This $21^{\text {st }}$ century jihad. This is a business that is more profitable for our rich men than sponsoring games and other worldly jamborees. In addition, an Islamic Education Trust Fund should be established to cater for the programme.

* Enlightenment Campaign: We should embark on vigorous enlightenment campaign showing the merits of this exercise and fruits of its success. This programme cannot achieve a huge success without the cooperation of all Muslims in education, administration, mass communication and economic sectors of our national life. Systematic campaign and enlightenment programmes should be given priority attention; otherwise the idea would be misconstrued and negatively presented to members of the public.

\section{References}

[1] Adedeji L., British Journal of Arts and Social Sciences 5(2) (2012) 273-282.

[2] Afzalur, A. R., (2000). Islamic Education of Muslim Children in the west and the problem of Curriculum and Syllabus, in Al-Afend, M. H., and Baloch N. A., (eds), Curriculum and Teacher Education, Jeddah, King Abdul Aziz University.

[3] Akinpelu, J., (2002) Philosophy of Adult Education. Ibadan. Sterling Horder.

[4] Al-Attas, S. N., (1979). Arms and Objectives of Islamic Education, Jeddah, King AbdulAziz University.

[5] Ekpo I., Journal of Educational for National Development 3 (1\&2) (2000) 111-113.

[6] Fafunwa, A. B., (1980). History of Education in Nigeria. George Allen and Unwin ltd, London.

[7] Kazi, Z., (2000). Who's who? Identifying Concepts and Entities Across Multiple Nigeria. In Proceedings of the Hawaii International Conference on Systems and Sciences. Hawaii.

[8] Khalil I. T., (2007). Islamization of Knowledge: A Methodology, Nigeria International Institute of Islamic Thought (IIIT) (Nigeria Edition).

[9] Olaoti, I. Y., (2010). Problems and Prospects of Islamization of Education in Nigeria. Source through: www.i - epistemology.net. Online Resources on Islamic Worldwide and Knowledge.

[10] Oloyede, I. A., (2008). The Imperative for Reshaping and Re-orientating the Modern Disciplines in the Islamic Perspectives. An unpublished Paper Presented at a Two-Day National Workshop on Islamization of Education.

[11] Qutub S. (1977). Islam: The Religion of the future, Beircut. The Holy Koran pushing House, Sahih al- Boukhari. 
[12] Sofolahan J. (2000). National Policy Issues in the State of Education III. Abuja UNESCO The Holy Quran, English Translation of the Meanings and Commentary (chapter 51:56). Medina King Fahd Holy Qur'an Printing Complex.

[13] Yoloye E. A. (2008). Vision and Mission of Special Education in Nigeria: Matters Arising and the challenges of the $21^{\text {st }}$ century in Kabiru Isyaku et al, (eds), Vision and Mission of Education in Nigeria, Kaduna, National Commission for Colleges of Education.

[14] Tomáš Hes, Anna Poledňáková, International Letters of Social and Humanistic Sciences 2 (2013) 18-31.

[15] Mohsen Mehrara, Masoumeh zirak, International Letters of Social and Humanistic Sciences 2 (2013) 32-38.

[16] Taiwo Adewale Muritala, Ismail O. Fasanya, International Letters of Social and Humanistic Sciences 2 (2013) 39-50.

[17] Borowski A., International Letters of Social and Humanistic Sciences 3 (2013) 46-53.

[18] Borowski A., International Letters of Social and Humanistic Sciences 3 (2013) 69-74.

[19] Donovan A. McFarlane, International Letters of Social and Humanistic Sciences 4 (2013) 35-44.

[20] Rajesh K. Yadav, Nishant Dabhade, International Letters of Social and Humanistic Sciences 4 (2013) 49-69.

[21] Borowski A., International Letters of Social and Humanistic Sciences 4 (2013) 70-74.

[22] Paul Bukuluki, International Letters of Social and Humanistic Sciences 5 (2013) 27-44.

[23] Mohsen Mehrara, Maysam Musai, International Letters of Social and Humanistic Sciences 5 (2013) 55-62.

[24] Debiprasad Mukherjee, International Letters of Social and Humanistic Sciences 6 (2013) 41-48.

[25] Tomáš Hes, Alena Neradová, Karel Srnec, International Letters of Social and Humanistic Sciences 7 (2013) 55-75.

[26] Kinga Dziwańska, International Letters of Social and Humanistic Sciences 7 (2013) 96-112.

[27] Borowski A., International Letters of Social and Humanistic Sciences 7 (2013) 113-118.

[28] Mohsen Mehrara, Maysam Musai, International Letters of Social and Humanistic Sciences 8 (2013) 1-7.

[29] Jacek Tittenbrun, International Letters of Social and Humanistic Sciences 11 (2013) 10-34.

[30] Mohsen Mehrara, Hamid Abrishami, Mostafa Boroujli, Mahan Amin, International Letters of Social and Humanistic Sciences 11 (2013) 76-83.

[31] Borowski A., International Letters of Social and Humanistic Sciences 11 (2013) 100-105.

[32] Sele Sylvester Ebisin, International Letters of Social and Humanistic Sciences 2 (2014) $1-9$.

[33] Tittenbrun J., International Letters of Social and Humanistic Sciences 2 (2014) 20-40.

[34] Borowski A., International Letters of Social and Humanistic Sciences 2 (2014) 110-121.

[35] Pawa Tersoo, International Letters of Social and Humanistic Sciences 3 (2014) 26-36.

[36] Rabi'u Muhammad Ishaq, International Letters of Social and Humanistic Sciences 3 (2014) 37-44.

[37] Adoga James Ada, International Letters of Social and Humanistic Sciences 3 (2014) 45-52.

[38] Bahram Meihami, Hussein Meihami, International Letters of Social and Humanistic Sciences 3 (2014) 80-91. 
[39] Kabiru Ibrahim Yankuzo, International Letters of Social and Humanistic Sciences 4 (2014) 1-8.

[40] Onyike Maggaret Odu, International Letters of Social and Humanistic Sciences 4 (2014) 31-39.

[41] Uloma Charity Oguzor, International Letters of Social and Humanistic Sciences 4 (2014) 97-104.

[42] Okezie A. Ihugba, Alex Odii, A. C. Njoku, International Letters of Social and Humanistic Sciences 5 (2014) 21-34.

[43] Okezie A. Ihugba, Bankoli Bankong, N. C. Ebomuche, International Letters of Social and Humanistic Sciences 5 (2014) 92-113.

[44] Borowski A., International Letters of Social and Humanistic Sciences 6 (2013) 86-90. 